\title{
Between Conflict and Peace: An Analysis of the Complex Consequences of the \\ Good Friday Agreement
}

\author{
John Nagle \\ Department of Sociology, University of Aberdeen, Aberdeen, UK, \\ j.nagle@abdn.ac.uk
}

\begin{abstract}
In the two decades since signing, the GFA continues to generate acrimonious debate over whether it has brought about sustainable peace or fomented weak and sectarian governance institutions. In this article, I review the formation and outworking of the GFA. In so doing, I go beyond either/or analyses of the GFA to identify the complex forms of political agency it has generated not necessarily envisioned by the Agreement's architects. I draw particular attention to the ways in which the central support beams of the Agreement - consociationalism and Europeanisation - have gradually become weakened to threaten the sustainability of power-sharing institutions.
\end{abstract}

Keywords: Good Friday Agreement, Northern Ireland, Consociationalism, Brexit, Devolution 


\section{Introduction}

After nearly 30 years of violence resulting in 3,700 deaths and circa 100,000 injuries (Morrissey and Smyth, 2002, pp. 3), the 1998 Good Friday Agreement (GFA) ${ }^{1}$ represented a new framework for peaceful political contestation to replace violent conflict as the key relationship between Irish nationalists and Ulster unionists. The architects of the GFA intended to realise this objective by crafting political institutions adhering to the principle of power-sharing and 'parity of esteem' for both group's identities. Yet the legacy of the Agreement twenty years after signing is profoundly contested. For advocates, there is a direct causal relation between the GFA and sustainable peace in Northern Ireland. In the words of former US Secretary of State Hilary Clinton (2014), 'Northern Ireland stands as an example to the world of how even the staunchest adversaries can overcome differences to work together for the common and greater good'. For more sceptical commentators, the GFA has instead acted to institutionalise sectarian divisions by rewarding the hard-liners of the rival blocs (Taylor, 2006). The Agreement’s dynamics, moreover, foment dysfunctional political institutions prone to periodic breakdown and a marked democratic deficit (Wilford, 2010).

In this paper, I review the formation and outworking of the GFA over two decades. In so doing, I go beyond either/or analyses of the GFA which measure its capacity to uniformly entrench or weaken ethnic cleavages by identifying the complex forms of political agency it has generated not necessarily envisioned by the Agreement's architects. I draw particular attention to the way in which the central support beams of the Agreement - consociationalism and Europeanisation - have gradually become weakened to threaten the sustainability of power-sharing

\footnotetext{
${ }^{1}$ There are alternative names for the Agreement, most commonly the Northern Ireland or the Belfast Agreement.
} 
institutions. The structure of the paper is organised as follows. In the first part of the article I examine the GFA's institutional design. The second part reviews the major events, actors and dynamics associated with power-sharing governments from 1998 to 2017. The final section debates both the chief successes and failures of GFA and assesses its future prospects.

\section{Ethnonational Diagnosis, Consociational Prescription}

The GFA reflected the dominance of the ethnonational interpretation of Northern Ireland's conflict (McGarry and O’Leary, 1995). In this analysis, clashing claims for nationalist self-determination stimulated violent conflict. Irish nationalists demanded the unification of the six counties of Ulster with the Republic of Ireland and Ulster unionists desired Northern Ireland to retain its position within the United Kingdom (Tonge, 2005). These mutually exclusive notions of political legitimacy buttressed a deeply divided society marked by enduring political and social cleavages, ranging from rival political parties, residential segregation and separate schooling systems (Nagle and Clancy, 2012).

Initially characterised by inconsistent strategies, the chief actors - especially the UK and Irish governments - eventually embarked on 'ethno-national policy learning' (O’Leary, 1997, pp. 673) to resolve the conflict. By the 1990s the governments sought a framework reflecting conflict's perceived ethnonational moorings. These frameworks broadly followed a consociational power-sharing format: the idea that conflict resolution in divided societies is best achieved through the accommodation of the political élites representing the salient ethnic or ethnonational groups and institutionally anchored by inclusive coalitions and proportionality in public appointments. 
A number of attempts to fashion sustainable consociational pacts in Northern Ireland failed. Yet the issue was not so much Northern Ireland's suitability for consociational influence; the issue concerned the parameters of classical consociational arrangements which were ill-fitting for complex self-determination conflicts like Northern Ireland. In particular, for power-sharing to be engineered for Northern Ireland's exigencies, it was necessary to take into account the conflict's ‘ethno-national, and bi-governmental, as well as bi-national’ (O’Leary, 1997, pp. 675) character. Northern Ireland was not only an internal ‘sectarian’ dispute; it also involved the UK and Irish governments as key actors.

To incorporate the complex set of issues and actors, the GFA comprises three strands. Strand One attends to the design of power-sharing institutions. The powersharing parliament - the Northern Ireland Assembly - forms the legislature containing 108 elected representatives. At the head of the Assembly is a ruling power-sharing executive led by a premiership dyarchy (the First Minister and Deputy First Minister possess identical powers) and a cabinet. Constitutional vetoes are given to unionists and nationalists in the Assembly and Executive for all key votes. While classical consociationalism had 'been overly fixated on the traditional sovereign and internationally recognized state’ (McGarry and O’Leary, 2006, pp. 249), Strands 2 and 3 of the GFA made provisions for the formation of institutional links between Northern Ireland and the Republic of Ireland and the UK. Strand 2 established crossborder governing arrangements between Northern Ireland and the Republic of Ireland, the North-South Ministerial Council (NSMC) and the North-South Implementation Bodies, which encourage cooperation between the two jurisdictions. Strand 3, alternatively, inaugurated institutional links between Britain and Ireland through the British-Irish Council and the British-Irish Intergovernmental Conference. In addition, 
the Agreement addresses other issues germane to the conflict: the release of paramilitary prisoners, the reform of policing, human rights, victims, and paramilitary weapons decommissioning.

At a broad scale, the GFA's framework is the product of two interconnected dynamics - liberal consociationalism and European integration. In combination, these dynamics form a mutually reinforcing relationship that aims to end a conflict hitherto framed as intractable (Whyte, 1981).

First, the GFA forms part of a relatively recent wave of divided societies falling under the influence of consociational power-sharing (Taylor, 2009). While consociations were once the results of informal pacts in places with linguistic or religious cleavages, Northern Ireland figures in a trend of consociations used to end political violence. Such is the prevailing orthodoxy among the international community regarding consociationalism's propensity to build peace and democracy, it is used or prescribed for Bosnia, Lebanon, Burundi, Kashmir, Macedonia, Afghanistan, Kenya, Syria and Iraq (Nagle, 2017). The GFA, however, has been called 'the brightest star in the new consociational universe' (Taylor, 2009, pp. 7). For proponents, the GFA represents an innovation on classical consociational arrangements by containing a ‘liberal’ structure (McGarry and O’Leary, 2006; McCulloch, 2014). While many consociations guarantee the representation of constituent ethnic groups by providing ethnic quotas in governance, in Northern Ireland voters can express voting preferences outside their ethnic blocs; there are no seats or political positions reserved for specific ethno-national groups; executive places are distributed among parties based on their electoral performances (McGarry and O’Leary, 2006). In practical terms, this means that ethnonational blocs could 
disappear if voters decided to put their support behind parties who advance nonethnic issues which cross-cut cleavages (Nagle and Clancy, 2010).

Northern Ireland's consociational arrangements are also inextricably tied to the project of regional substate devolution expedited by Tony Blair's New Labour government from 1997 onwards (Tonge, 2005). This experiment, which also included Wales and Scotland, was rolled out - albeit in an asymmetrical fashion - to tame secessionist nationalisms across the UK. The British government hoped devolution would be acceptable to both nationalists and unionists in Northern Ireland. To deal with separatist nationalists, devolution would peacefully accommodate their national identities and give them a say in regional politics. For reformist unionists it was a means to gain some regional powers within a reconstructed state, yet simultaneously retaining the jurisdiction of the state. Both sides, therefore, could present devolution as increasing the democratic representation of their respective groups while concurrently strengthening their national aspirations.

Second, the GFA is shaped by the European Union's approach to resolving territorial disputes (Tonge, 2016; Guelke, 2017). The EU emerged as a response to the destruction caused by irredentist conflicts, especially where national minorities desired unification with their homeland state. Conflict management is achieved through two steps. First, integration is founded on affirming the territorial status quo, which requires member states to revoke territorial claims in neighbouring states. Second, states are required to recognise and promote the rights and identities of their substate national minorities. In combination, these two aspects made it possible to soften borders to facilitate peaceful transborder links between minority groups and their homeland. In the most radical of these analyses, European integration augurs a ‘truly postmodern international political form' (Ruggie, 1993, pp. 140) in which state 
sovereignty is increasingly decoupled from territory to allow for complex forms of governance involving networks binding multiple states. Thus, in the GFA, the Republic of Ireland swapped its constitutional claim over Northern Ireland for the North-South Institutions and the UK agreed to subscribe to minority rights protections. Indeed, the architects of the peace process clearly viewed the GFA's architecture as profoundly facilitated by EU integration.

\section{Constructive Ambiguity and Institutional Collapse}

The GFA was signed on 10 April 1998. Since the negotiations leading to the deal were largely a secretive, elite driven affair, it was decided that the Agreement required popular consent to be seen as deriving legitimacy. A referendum on the Agreement, held on 22 May 1998, was supported by 71.1\% of voters in Northern Ireland, with a turnout of 81.1\% (Hayes and McAllister, 2005, pp.152). In June, the first election for the Northern Ireland Assembly saw the two main unionist parties gain 48 seats (UUP 28 and the DUP 20), the two nationalist parties secure 42 seats (the SDLP winning 24 seats and Sinn Féin 18), and the non-sectarian Alliance Party and Women’s Coalition with 6 and 2 seats respectively (Evans and O’Leary, 2000, pp.79).

Earlier attempts to forge power-sharing governments aimed to bring together the moderate centre ground of Northern Irish politics thereby excluding the hardliners (Hayes and McAllister, 2005, pp.148). The logic underlying this approach was that it would haemorrhage whatever support the radicals of nationalism and unionism could claim as legitimating their violent methodologies (Horowitz, 2002). The GFA represented an opposing rationale: that power-sharing should be inclusive by accommodating both moderates and hardliners (Tonge, 2005). The hope was that the 
men and women of violence could be brought in from the cold; yet the danger was that the hardliners would bring the cold in with them.

To ensure inclusivity and moderation, elections for the Northern Ireland assembly utilised the PR-STV electoral system, in which voters are given as many preferences as there are candidates in each constituency and they are allowed to rank in order their preferences. In theory, PR-STV allows comprehensive inclusion by rewarding 'those who engage in accommodative behaviour' (Mitchell, 2008, pp.15), since candidates are incentivised to seek lower preference votes from citizens outside of their ethnic bloc.

The 1998 Assembly elections achieved strong inclusivity and only modest signs of inter-ethnic vote-pooling (McEvoy, 2015). On the one hand, representatives from both the so-called moderate and hardline parties of nationalism and unionism were elected to government. On the other hand, some evidence of lower preference vote transfers between the moderate candidates of nationalism and unionism that supported the Agreement took place. Little indication, however, of voters using their secondary and lower preferences to vote for candidates outside of their ethnonational bloc occurred (Evans and O’Leary, 2000).

Inclusion and moderation were further enshrined in the NIA through the use of the d'Hondt mechanism to allocate ministerial positions in the ruling Executive (Tonge, 2005, pp.151). The d'Hondt algorithm is designed to promote inclusion by apportioning cabinet seats based on the number of seats a party has in the Assembly. This mandatory rather than voluntary coalition of executive power-sharing aims to capture a full spectrum of the political community regardless of whether this includes extremists, moderates and non-ethnic parties (McEvoy, 2015, pp.70). The first 
executive fulfilled this ambition by containing ministers from the four major parties (UUP, SDLP, DUP and Sinn Féin).

The 1998 NIA election resulted in the moderate wings of nationalism (SDLP) and unionism (UUP) being instilled as the largest parties in their respective ethnonational blocs. The leaders of these two parties - David Trimble (UUP) - and Seamus Mallon (SDLP) - were nominated by the NIA to take up the posts of First and Deputy First Minister to lead the Executive. The SDLP and the UUP represented the traditional leaders of nationalism and unionism. Both the UUP and the SDLP advocated peaceful political means to advance opposing constitutional preferences for Northern Ireland. These parties spoke primarily though not exclusively to middle class voters who shunned the violence deployed by paramilitaries. The SDLP and to a lesser extent the UUP were also leading architects and negotiators of the GFA (McEvoy, 2015, pp.70). For the UK and Irish governments, the future stability of power-sharing and the GFA relied upon a centrist bloc led by the UUP and the SDLP maintaining leadership within their communities (Clancy, 2010). The consensus building approach of these moderates would demonstrate the benefits of the new power-sharing institutions to the wider population, thereby starving the extremists of the popular support required to wreck the Agreement through violence (Horowitz, 2002).

At the GFA's outset, the ability of the centrist parties to maintain control within their ethnonational blocs was weak. In contrary to the supposedly ameliorative properties of PR-STV, voters for the centre parties - the SDLP and the DUP transferred their allegiances to the putative hardliners within each community - Sinn Féin and the DUP. In the 2003 NIA election, Sinn Féin - viewed as the political wing of the IRA - overhauled the SDLP as the largest nationalist party and the DUP, which 
campaigned against the GFA, became the dominant unionist party. Rather than a temporary condition, the so-called 'triumph of the extremes' signified an enduring realignment of nationalist and unionist politics that remains today. While the British and Irish governments initially feared that Sinn Féin and the DUP’s dominance would destabilise the GFA, they eventually accepted that these two parties formed the axis around which power-sharing is sustained (Clancy, 2010).

The electoral evisceration of the SDLP and the UUP at the hands of Sinn Féin and DUP can be ascribed to four broad factors. First, the GFA provided an exercise in ‘constructive ambiguity’ (Dixon, 2002), the premise that it could be sold to nationalists and unionists as simultaneously advancing their rival aspirations. Rather than resolve the question of self-determination, the GFA incentivised those who could successfully frame themselves as the best parties to either deliver Irish unity or secure the long-term future of the union. Sinn Féin and the DUP both took unwavering oppositional positions on the constitutional question.

Second, from inception, the GFA found weak unionist support in contrast to the near unanimous level of Irish nationalist backing. This discrepancy underlined the perception that the GFA was more favourable to nationalists than unionists. To an extent the deficit was a product of poor salesmanship by pessimistic unionist elites lacking the conviction to promote the benefits of the GFA to their voters. In a society dominated by zero-sum ethnonationalist politics, the discourse of constructive ambiguity worked to construct a framework in which concessions gained by one group are experienced as a defeat for the other. For Irish nationalists, the GFA was framed in positive and victorious terms. It represented the institutional expression of the 'equality agenda', a positive process of redressing the historical experience of inequality and exclusion of the nationalist population. For unionists, the Agreement 
was felt as a loss, and the equality agenda - such as the reform of policing - were seen as a nationalist-led creeping barrage to hollow out unionism (McAuley and Tonge, 2010). By 2003, unionist support for the Agreement slowly eroded, a dynamic successfully seized on by the DUP to castigate the UUP as weak defenders of unionism.

Third, the fortunes of the Agreement were predicated on all the key aspects being rolled out in a process of quid pro quo between nationalist and unionist parties (Tonge, 2005). For Sinn Féin, a major condition for Irish republicans to support the GFA was the release of all Irish republican political prisoners, the release of which, according to unionists, was contingent on Irish republicans reciprocating by beginning a process of decommissioning their weapons (Clancy, 2010). Again, the discourse of constructive ambiguity, deemed necessary to gain the consent of the main parties, was shown to be weak when faced with competing demands. Sinn Féin claimed that the text of the GFA only required that the governing parties seek to persuade the paramilitary organisations to hand over weaponry. The UUP argued that immediate and substantial acts of decommissioning formed a non-negotiable element of the GFA (Clancy, 2010). With no evidence of progress towards decommissioning, the British government suspended the Assembly and the Executive in February 2000 followed by the resignation of David Trimble as First Minister in July 2001.

In addition, while Sinn Féin and the DUP expertly manipulated the GFA to become leading parties, these parties underwent important internal changes to allow them to take advantage of its opportunities (Evans and Tonge, 2009). This situation was particularly evident in the rise of Sinn Féin’s electoral fortunes. Sinn Féin only began contesting elections in its modern form from 1982. At this point, Sinn Féin articulated unambiguous support for the IRA's armed campaign and opposition to the 
very existence of the Northern Ireland state. While it's an exaggeration to say that Sinn Féin experienced a complete transformation during the peace process, the party outwardly moderated on many issues to the extent that it was able to expand its electoral base beyond its traditional working-class republican constituency to capture the votes of middle-class nationalists once seen as the preserve of the SDLP (Evans and Tonge, 2009, pp.1016). In the power-sharing executive, Sinn Féin gained vital experience helming the two largest ministries, health and education, which bolstered its image as a party of ‘delivering government’. Sinn Féin’s rebranding strategy reaped rewards: over one-third of its 2003 voters did not support the party in the 1998 contest (Mitchell et al., 2009).

Compared to Sinn Féin, the DUP's move to the moderate centre of Northern Irish politics appeared less obvious. In fact, outwardly the DUP electorally usurped the UUP through a classic example of ‘ethnic outbidding' (Mitchell et al., 2009), a dynamic in which parties outdo rivals in demonstrating their suitability to defend their ethnic community. Led by Ian Paisley, the DUP vociferously opposed the GFA from the outset. It walked out of the multiparty talks as a protest against the inclusion of Sinn Féin in the process and it campaigned for a 'no' vote in the referendum. Adopting a half-in, half out approach to power-sharing, the DUP took its Assembly and ministerial seats while simultaneously boycotting meetings and opposing decisions agreed by the Executive (McEvoy, 2015). Yet, despite the DUP’s implacable public opposition to the terms of the GFA, inexorably the party was moving closer to the centre ground of Northern Irish politics in that it accepted the necessity of power-sharing institutions, albeit on the basis that they needed to be refashioned on more favourable terms for unionists (Mitchell et al., 2002). 


\section{St Andrews: The Triumph of the Hardliners or the Rise of Ethnic Tribunes?}

The confirmation in September 2005 that the IRA ‘destroyed all its arms’ provided the impetus for DUP and Sinn Féin - now the two largest parties - to restart powersharing through the St Andrews Agreement (Northern Ireland Office, 2006). In order to incentivise the DUP to enter into power-sharing, St Andrews committed Sinn Féin to supporting policing and the criminal justice system, which, by extension, represented that party's assent to the legitimacy of Northern Ireland's current constitutional position. The DUP, for their part, agreed to fully participate in in all the institutions (Wilford, 2010).

St Andrews further included key adjustments designed to improve the stability and effectiveness of power-sharing. It would be remiss not to remark upon the 19982002 power-sharing government's achievements, including the introduction of free public transport for everyone over 60, the appointment of a Children’s Commissioner, and the publication of a new regional strategy (McEvoy, 2015, pp.81). Yet, the d'Hondt formula for the sequential allocation of ministerial portfolios permitted individual ministers to embark upon solo policy runs leading to accusations that the mandatory coalition permits cabinet ministers to operate de facto 'party fiefdoms' (Tonge 2009: 52). Thus, a statutory ministerial code was created under St Andrews to foster ‘joined-up government’ by enhancing ministerial accountability (Wilford, 2010).

The modifications to the Good Friday Agreement specified in St Andrews did little to fundamentally alter the 'constructive ambiguity' at the heart of the peace process. For unionists, the revised Agreement still represented the fortification of the union, while nationalists continued to frame it as a port of call en route to Irish unification (Wilford, 2010). In a new power-sharing context headed by the DUP and 
Sinn Féin a reasonable anxiety concerned the long-term feasibility of a partnership of convenience. The narrow ground of moderate Northern Irish politics required for the political elites of unionism and nationalism to engage in interethnic compromise remained straitened. Hopes that the post-St Andrews political dispensation would augur a new future of cooperation through power-sharing appeared Panglossian when Gerry Adams, Sinn Féin's President, predicted that the restored institutions would be embroiled in 'battle a day’ (BBC, 2005). These fears were lessened by the astonishing images accompanying the re-launch of power-sharing featuring Ian Paisley and Martin McGuinness - a former PIRA chief of staff - sharing a joke as they were announced as First and Deputy First Minister. Given the sobriquet of 'the Chuckle Brothers', political commentators voiced surprise at the unlikely bromance between McGuinness and Paisley that transformed power-sharing into a 'giggle a day'.

The nascent partnership between the First and Deputy First Minister provided evidence that the peace process represented a 'triumph of the extremes but not a victory for extremism’ (McCulloch, 2014, pp.73). Instead of power-sharing becoming infected by further rounds of ethnic outbidding, Sinn Féin and DUP demonstrated a capacity to engage in moderate behaviour. To capture this effect, Evans et al (2009) coined the term 'ethnic tribune parties' to describe Sinn Féin and the DUP in government. These parties combine pragmatic support for the principles of cooperative power-sharing with robust policies seen to be defending their community's interests within government. Yet, rather than a successful example of consensus politics, for some critics the new era of equanimity appeared little more a sectarian carve up between Sinn Féin and the DUP - or what one detractor called the ‘Molotov/Ribbentrop pact by the Lagan’ (Godson, 2003). 
Open for Business: Northern Ireland plc

A key indicator of the new power-sharing government's intentions was its willingness to support the Shared Future policy recommendations. Shared Future (OFMdFM, 2005) was published in 2005 under the auspices of the Office of the First Minister Deputy First Minister. Shared Future’s overarching narrative stressed the importance of tackling sectarianism and social exclusion and by encouraging integrated schooling and housing. Both Sinn Féin and the DUP challenged the recommendations of Shared Future by launching an alternative, the Programme for Cohesion, Sharing and Integration (OFMdFM, 2010, pp.1), which expressed a desire for 'a future based on sharing, equality, respect and understanding'. Lacking policy detail its ambition was 'managing a divided society rather than about tackling the root causes, part of the legacy of violence where reconciliation comes before systemic changes' (Knox, 2011: 563).

It was no surprise that the Executive’s Programme of Government (PfG) contained little that was recognisable from Shared Future. Indeed, the title of the PfG, ‘Building a Better Future’ (OFMdFM, 2007) - rather than 'Shared Future’ signposted the Executive's moderate objectives in relation to dealing with segregation and sectarianism. In eliding practically any reference to peace, reconciliation and community relations, the 2008 PfG outlined how economic growth precipitates the amelioration of the divided society, rather than the elimination of sectarianism and segregation as a prelude to prosperity. For a number of commentators, 'Building a Better Future’ exemplified a neoliberal turn to stimulate peace and equality in Northern Ireland (Nagle, 2009; Murtagh and Shirlow, 2012). In particular, the document outlined the government's adherence to the virtues of free-market enterprise, private-finance initiatives to bolster public services, and foreign-direct- 
investment. These policies provided a rare form of consensus across the political divide. The power-sharing government announced that 'Northern Ireland PLC' was now ‘open for business’ (Nagle and Clancy, 2010, pp.190).

The power-sharing administration (2007-2011) was the first in over 40 years to run for a full parliamentary term and it implemented a number of key policies, including the devolution of policing and justice. Yet, the government failed to deliver on its main policy pledges, especially health, education and the economy and the executive failed to agree on implementing policies flagged in the GFA - a concerted community relations policy, a single Equality Act or a Northern Ireland Bill of Rights (Wilford, 2010, pp.149-150).

These policy failures can be ascribed to a number of factors. First, the UUP and the SDLP viewed the Executive as a Sinn Féin/DUP sectarian stitch up rather than a genuine multiparty coalition. Feeling politically excluded, the UUP and the SDLP individually moved towards a position of de facto opposition. In the Executive, the UUP and SDLP held their ministerial portfolios but simultaneously acted as oppositional voices within meetings and voted against the budget. Second, the honeymoon period between the DUP and Sinn Féin quickly subsided. Under pressure from DUP hardliners, Ian Paisley resigned as First Minister in May 2008. His replacement as party leader and First Minister, Peter Robinson, adopted a more adversarial approach in relation to Sinn Féin leading to the epithet 'Brothers Grimm’ as a replacement of the 'Chuckle Brothers'. Both the DUP and Sinn Féin strategically deployed their veto to block legislation they framed as harmful to their community's putative interests. The DUP, in particular, vetoed an Irish Language Act, which Sinn Féin responded to by boycotting a number of Executive meetings and threatening to 'pull the plug' on the Assembly. 


\section{1-2016: Bread and Butter or Pork Barrel Politics?}

The relative stability of power-sharing encouraged a comparatively muted campaign for the May 2011 Assembly elections. Voter turnout dropped to 54.7\% compared with 62.3\% in 2007 (Russell, 2011). On the one hand, it could be argued that voter absence indicated the decline of electoral campaigns organised around polarising sectarian narratives. Northern Irish politics, in this analysis, was increasingly normalised as evident by the dominance of 'bread and butter' rather than 'pork barrel' issues (Matthews, 2012). On the other hand, the same dynamic could be read as symptomatic of increasing voter apathy at a power-sharing government revolving around a DUP/Sinn Féin axis which delivered few substantive policies.

The electoral results provided a strong mandate for Sinn Féin and the DUP. Both parties increased their tally of seats and share of first preference votes while the UUP, SDLP and centrist cross-community Alliance lost further ground. The strengthening of DUP/Sinn Féin's combined hold over the Executive inspired some optimism that the power-sharing government could exercise the imagination to go beyond peace process politics to become exponents of the art of governance.

Symbols, however, provided both an opportunity for intergroup compromise and for conflict to materialise. On the plus side, the political elites of nationalism and unionism displayed bold reconciliatory gestures. Most notably, in June 2012 Martin McGuinness and the Queen publically shook hands. On the deficit side, symbols provided a context for sectarian identity politics to threaten power-sharing. In particular, the decision of Belfast City Council’s policy committee to restrict the flying of the Union flag atop city hall from all year round to fifteen designated days a year led to violent protests from sections of the unionist population. In all, the 
protests, which spread across Northern Ireland, witnessed injuries to hundreds of police officers, politicians receiving death threats, and the burning down of a political party’s office (Nolan et al., 2014).

The issue was particularly destabilising for power-sharing given the DUP's instrumentalisation of the protests. The DUP's involvement in the imbroglio stemmed from its leader, Peter Robinson, losing his East Belfast Westminster seat in 2010 to the cross-community Alliance Party, who successfully courted a large number of unionist voters. With the objective of winning back the seat, the DUP sought opportunities to lessen the Alliance Party in the eyes of unionists. The vote on the flying of the Union flag presented such an occasion since the Alliance Party suggested the compromise motion of restricting the flying of the flag. In the run up to the vote, the DUP printed 40,000 leaflets accusing the Alliance Party of anti-unionist sentiment and which called for unionists to take to the streets to protest (Nolan et al., 2014).

At a broader scale, the flag dispute exposed some of the inherent weaknesses of the GFA. The core precept of 'parity of esteem' - read to mean that the identities of both groups should be awarded equal recognition - did not create a spirit of multicultural intergroup tolerance as desired. Instead, parity of esteem provided a context for zero-sum recognition clashes between nationalists and unionists as the groups refused to award esteem to many of the other's national identities and symbols. Thus, while the Agreement provided a context for the successful resolution of many core institutional issues - such as the design of power-sharing arrangements - so-called secondary order matters connected to identity were left unsettled. Notably, many of the most disrupting events during the peace process related to divisive symbols and rituals, such as Orange Order parades (Nagle, 2014). 


\section{Austerity Bites: Stormont House and Fresh Start}

The New Labour government oversaw the signing of GFA and the period to 2010. Tony Blair, Prime Minister from 1997-2010, invested a great deal of effort in the peace process, which he identified as a major personal success. The victory of the Conservative Party under the leadership of David Cameron in the 2010 UK General Election appeared at first glance to bring a government into power more favourably disposed to unionism. As a self-declared 'One Nation Conservative’, Cameron declared his intention of bringing Northern Ireland more firmly into the mainstream of British politics. Cameron's government, however, maintained continuity with New Labour in relation to articulating a position of rigorous impartiality and support for devolved power-sharing.

The main consequence of the Conservative administration for power-sharing concerned that government's adoption of austerity policies. These policies were acutely felt in Northern Ireland where the economy continued to rely heavily on the public sector and from the block grant distributed according to the Barnett Formula. The UK Welfare Reform Act 2010-12 was introduced by David Cameron’s government as part of its programme of austerity aimed at reducing welfare spending across the UK. Sinn Féin objected to the imposition of welfare reform in Northern Ireland and the Executive's inability to agree on the policy threatened to once again return power-sharing to its perennial condition of precariousness. The UK and Irish governments convened eleven weeks of 'crisis' multiparty talks to clear the imbroglio. The resulting Stormont House Agreement (Northern Ireland Office, 2014) outlined a number of undertakings to resolve outstanding issues. The UK government agreed to send an extra £2bn so that the Executive could mitigate the effects of welfare reform. In addition, the Agreement advanced measures designed to reform 
dysfunctional power-sharing institutions by pledging to reduce the number of MLAs in the engorged Assembly and the number of government departments, and make provisions for an official opposition bloc to be mandated.

The implementation of The Stormont House Agreement quickly stalled. In 2015 Sinn Féin lodged Petition of Concerns - effectively communal vetoes - to block the Welfare Reform Bill. The precarious situation worsened in August after the police stated that IRA members might have been involved in a murder thus implying official recognition of the IRA's continued existed. In response, the UUP withdrew from the Executive followed shortly by the DUP pursuing a strategy of rolling resignations from the Executive. In emergency, redux, the UK and Irish governments convened a further ten weeks of multi-party 'crisis talks'. Entitled the 'Fresh Start Agreement' (Northern Ireland Office, 2015), more cynical commentators branded it the 'Groundhog Day Agreement' given its familiar pattern. Fresh Start outlined the release of a further $£ 585$ million to relieve the impact of austerity policies and steps to deal with on-going criminality and paramilitarism.

\section{6-2017: A Tale of Three Elections}

2011-2016 marked a consecutive period of government without an interregnum, a fact tempered by episodic acts of brinksmanship. In one sense, the 2016 Assembly elections gave further evidence of the willingness of the electorate to reward the Sinn Féin/DUP duopoly as both parties remained ensconced as the leading parties. There was a distinct policy overlap between the two parties 'designed to bolster the notion that only the DUP and Sinn Féin could provide stable, effective government in Northern Ireland' (Coakley et al., 2017, pp.12). The election particularly represented a personal vindication of Arlene Foster's selection as new DUP leader as the DUP's 
campaign refrain, 'Keep Arlene as First Minister', clearly acted as a rallying call to unionists to stop Sinn Féin from claiming the post of First Minister. Sinn Féin remained the second largest party with 28 seats, but its vote share dropped by $2.9 \%$ (Russell, 2016). The results augured troubling news for Sinn Féin since this was the first post-GFA election that the party recorded losses, exposing in turn the party's narrative of nationalism's teleological march towards Irish unity (Coakley et al., 2017). Optimism that Northern Ireland's electorate were willing to transcend the traditional binaries of ‘orange’ and 'green’ politics were given some qualification in the strong performance of the non-sectarian People Before Profit and the Green parties. Signs of an emerging new political axis were further evidenced when the UUP and then the SDLP confirmed that they would not take their ministerial seats and instead form the first official cross-community opposition in Stormont.

By the end of 2016, events conspired to infect power-sharing with fresh paralysis due to two separate but ultimately reinforcing events. First, in June the results of the EU referendum led to a victory for the Leave campaign. The voters of Northern Ireland overwhelmingly supported remain by a margin of $55.78 \%$ to $44.22 \%$. Only the DUP of the major parties campaigned to leave, though to an extent voting mapped onto traditional ethnonational demographics (Tonge, 2016, pp.338). Irish nationalists argued that Brexit threatened to unravel not only the GFA but the peace process. Second, in December details of the mismanagement of the Renewable Heat Incentive Scheme were exposed as causing a $£ 490$ million government overspend. As Arlene Foster presided over the scheme, Sinn Féin demanded her resignation, which the DUP rejected. When Sinn Féin’s Martin McGuiness resigned as Deputy First Minister in January 2017 in protest, Sinn Féin refused to nominate a replacement automatically collapsing power-sharing. 
The first interregnum of power-sharing in a decade automatically triggered an Assembly election for March 2017. The election provided propitious ground for Sinn Féin to mobilise the nationalist electorate. Beyond Brexit and 'Cash for Ash', Sinn Féin critiqued the DUP for vetoing an Irish Language Act, which Sinn Féin claimed revealed unionists traditional sectarian intransience to recognising nationalist identities. The heated atmosphere of the election campaign drew voters to polling stations, evident by the official turnout of $64.8 \%$, an increase of 9.9 percentage points on the May 2016 figure (54.9\%) and the largest since 1998. Although the election results reconfirmed the status of the DUP and Sinn Féin as the two leading parties, the margin of first preference votes between the DUP and Sinn Féin narrowed to 1,168 votes. In terms of Assembly seats, which had been reduced from 108 to 90, the DUP now held 28 seats compared to Sinn Féin’s 27 (Russell, 2017). Despite recording a slight rise of first preference votes, the UUP were reduced to 10 seats, a poor performance many commentators ascribed to UUP leader Mike Nesbitt's brave and perhaps risky comments that he intended to give his second preference vote to the SDLP rather than to another unionist party. While the UUP leader's call for a 'postsectarian political' system largely failed, the cross-community Alliance Party saw the largest proportionate increase in first preferences, from 48,447 in May 2016 to 72,717, a rise of 50.1 per cent (Russell, 2017).

If the 2016 Assembly election results were disquieting for Sinn Féin, the 2017 election created an existential crisis for unionism given Northern Ireland's formation was to maintain an inbuilt unionist majority. Not only had the DUP slipped under the 30 seats threshold required to exercise sole veto power, but unionist parties have a combined total of 40 seats out of 90 , which means that for the first time in Northern Ireland's history, unionists now constitute a political minority. 
A third election in just over a year exposed the degree to which the local weaknesses of power-sharing made it subject to the expediencies of wider UK national politics. UK Prime Minister Theresa May’s decision to call a snap Westminster election in June 2017 backfired as the Conservative Party lost its parliamentary majority. In response, the DUP agreed to enter into a 'confidence and supply’ agreement to prop up the beleaguered government. Though a relatively informal pact, the Conservative government's nascent alliance with the DUP was alleged in some quarters - including a former Conservative prime minister - to threaten the peace process, particularly since it signalled that the government would potentially be in breach of its impartial brokerage duties specified in the GFA.

\section{Assessment}

'It's too soon to know', Zhou Enlai’s apocryphal assessment of the French revolution's consequences appear equally apposite to the GFA. Approaching its 20th anniversary, the GFA's long-term imprint on Northern Ireland remains difficult to discern. A major reason for this is the inherent polysemy of the GFA - from the outset a range of groups interpreted the Agreement as providing ripe potential to allow them to pursue radically opposing ambitions. For Gerry Adams, Sinn Féin president, the GFA represented 'the Trojan Horse of the entire republican strategy' (BBC, 2014) in its objective to secure a united Ireland. For unionists, the triple lock features enshrined in the consent principle clearly safeguarded Northern Ireland's enduring position in the UK. For those occupying the political centre ground, the GFA set out a template for a shared future in which sectarian allegiances would be eroded by ever increasing integration and reconciliation. 
Almost two decades on from the GFA, these narratives remain largely undiminished. The question of whether the GFA has increased the likelihood of any of them being realised is difficult to determine. Rather than embodying a set of isomorphic institutions that generate predictable outcomes, the GFA has expedited complex forms of agency not necessarily intended by its architects. Towards an understanding of these effects, the article concludes by reviewing how the two main beams supporting the GFA - consociationalism and Europeanisation - have loosened in a way that potentially threatens to unravel the Agreement. In particular, I note that given that the GFA is nested within multiple layers involving UK, European and international political contexts and institutions, the current reversal or fragility of these processes - especially due to Brexit - have a major impact on the future sustainability of the Agreement.

\section{Consociationalism}

For proponents of power-sharing there is 'hard evidence that the peace process has brought greater security and stability because it was attached to an inclusive consociational settlement’ (McGarry and O’Leary, 2006, pp.264). By encouraging ethnic hardliners to abandon physical force for political representation, Northern Ireland has clearly undergone a major reduction in political violence. In addition, while Northern Ireland's consociational institutions facilitated the success of the reputed hardliners of unionism and nationalism, it also encouraged these parties to moderate once they grasped the reins of power. In comparison to a number of other consociations in divided societies across the world, Northern Ireland is not blighted by the same levels of corruption, clientelism and dysfunctionalism (Nagle, 2017). 
Yet, there remain questions about why the progressive or even emancipatory potential of consociationalism failed to sufficiently emerge. Northern Ireland's power -sharing arrangements are characterised by a problem endemic to many other consociations. Consociations are meant to be provisional arrangements that encourage belligerent groups to abandon violence for constitutional guarantees of representation in the polity (McCulloch, 2014). Yet, in turn, through safeguarding representation, a new predicament arises regarding how to transition to a more flexible system that affords an opportunity for the depoliticisation of ethnicity (Nagle, 2016). Rather than aspirational, the idea that power-sharing can 'provide a hospitable environment for the erosion of difference' (Coakley 2009, pp.145) is a core hope. The logic of consociational proponents is that the building of trust at the elite level would gradually descend to envelop contending communities, thereby leading to the erosion of ethnic cleavages.

Ethnicity remains deeply politicised in Northern Ireland. While the design of PR-STV is intended to encourage voters to use their second preferences for candidates outside their ethnonational bloc, the overlap between religion and voting habits in Northern Ireland remains the strongest in Western Europe (Coakley et al., 2017). Ethnicity and, by extension, sectarianism continues to be an instrument wielded by the main political parties to mobilise supporters. A key battleground of ethnosectarian politics is the distribution of public goods, which are supposed to be divvied up among the main groups according to consociational principles. In consequence, as Shirlow and Murtagh (2006) note, the Agreement expedites a 'stale and repetitive pattern of ethnically-divided competition over resources’. Fierce communal-based debates have arisen over distributive issues, like where a hospital should be sited. Since it is alleged that the Agreement fails to tackle the problems of 
endemic segregation across the region, a situation has emerged whereby public services are duplicated for nationalist and unionist areas. The cost of division, it is claimed, is $£ 1.5$ billion per annum (Deloitte, 2007). The inability of the GFA to lessen sectarian politics has a correlative impact on community relations; according to one expert, ‘devolution has been accompanied by greater pessimism’ (Morrow, 2015, pp.1) that intergroup relations will improve in the future.

Moreover, while the liberal consociationalism the GFA is much lauded, power-sharing in Northern Ireland has become increasingly more corporate in character. For example, the system of community designation used for voting in the Assembly was modified in the St Andrews Agreement to limit the ability of MLAs to switch their official identities. Under the auspices of St Andrews, the system of communal designation was extended to the Executive thus, in essence, enshrining the veto power of the main ethnonational groups, which is read as a proxy for corporate guarantees. In some quarters, communal designation is accused of operating to entrench communalist politics (Taylor, 2006). The usage of the veto system has increased rapidly. While 40 petitions of concern were tabled between 1998-2011, the number increased exponentially to 118 in the 2011-2016 legislative session (McCulloch, 2017). Instead of a protective mechanism designed to safeguard the interests of the respective ethnonational communities, the veto has become a 'blocking move' and an abuse of its original intention. The main ethnonational parties have deployed their veto in areas of policy that are not clearly specified as clearly communal. Most notably, the DUP have exercised their veto prerogative to stymie same-sex marriage (Hayes and Nagle, 2016) and Sinn Féin stopped the passage of welfare reform. 
The failure of the Assembly to enact same-sex marriage legislation exposes a further issue regarding Northern Ireland's consociationalism: its implications for social groups - such as feminists, socialists, migrants, and sexual minorities - whose primary political identities are not included in power-sharing. For example, Hayes and McAllister (2003) highlight the difficulty of reconciling consociational pacts with the desire for gender equality. Women are consistently less likely to support powersharing institutions compared with men as gender issues - such as abortion rights have been side-lined in power-sharing.

A compounding effect is the mandatory rather than voluntary style of government undergirding Northern Ireland's power-sharing. Although the point of this grand coalition is to transform opponents into partners, it is accused of resembling a 'holding company’ (Wilford and Wilson 2006, pp.27) rather than incentivising coalition building and a shared strategic vision. In enshrining inclusive government, the mandatory coalition lacked a notable opposition bloc, which is required to promote transparency and accountability. ${ }^{2}$

\section{Europeanisation}

The GFA is expedited by bilateral treaty relations between the UK and the Republic of Ireland and North-South institutions, all of which are facilitated by - though not formally predicated upon - the UK and Ireland both being EU member states (Tonge, 2016; Guelke, 2017; Schwartz, 2017). The North-South institutions, in particular, are designed to facilitate relevant EU matters, including the EU Programme for Peace and Reconciliation in Northern Ireland, which has overseen the distribution of 1.3 billion euros for peacebuilding projects (Tonge, 2016). The adverse effects of Brexit,

\footnotetext{
${ }^{2}$ To remedy this issue, the Opposition Reform Bill, which passed into legislation March 2016, now provides institutional support for an opposition bloc in power-sharing (Russell, 2016). It is hoped that this initiative will encourage greater accountability of the Executive.
} 
therefore, are most likely to be felt in Northern Ireland. Brexit could result in a $£ 300$ million shortfall to Northern Ireland's budget (Guelke, 2017, 50) and it presages the possible return of a hard border - replete with customs and posts and security checkpoints - between the North and the South thus ending the common travel area between the two jurisdictions. Equally important, the EU provided the context for close cooperation between UK and Republic of Ireland to flourish, which laid the platform for their joint approach to the GFA.The threat Brexit poses to the GFA and even the peace process requires new and creative forms of political thinking to minimise the potential harm. Towards this, a number of proposals are mooted, including the 'EEA Option', in which the UK would leave the EU but Northern Ireland (and not the rest of the UK) would remain part of the European Economic Area (Guelke, 2017; Schwartz, 2017)

\section{Conclusion}

At the time of writing (June 2017), Northern Ireland's power-sharing institutions are suspended. Power-sharing appears at its most precarious state for over a decade and the augurs for the future of the GFA are not good. Yet, faith need not be abandoned. Survey data continues to demonstrate that devolved power-sharing is the preferred choice for Northern Ireland's population, beyond the either or binary of a united Ireland or direct rule from Westminster. It is clear that ethnonational identities are not simply withering away; but to an extent the antagonistic aspect of these identities have lessened. While the premise of a shared Northern Ireland identity that transcends ethnic particularisms is fanciful, voters have displayed a willingness in recent elections to vote for non-sectarian candidates and parties. At a demotic level, Northern Ireland's population increasingly dwell in shared cultural spaces, evident to 
some extent in the popular support for the Northern Ireland football team, which was once rejected by nationalists as bastion of unionism and sectarianism. To a degree, there appears to be a lag between the political elites - especially the DUP and Sinn Féin - and their supporters, who articulate more positive attitudes towards social issues, such as abortion rights. In order to take advantage of this emerging culture of conviviality and liberalism, it is necessary for the elites to demonstrate an imaginaire which sees the GFA as not a holding operation but as an instrument for societal transformation so that Northern Ireland truly merits the title of a 'post-conflict' society. However, as illuminated in this paper, the precariousness of the GFA due to weak consociational institutions and the consequences of Brexit risk stymieing and even reversing progress. 


\section{References}

BBC (2005) 'Text of Adams Speech in Full', accessed at: http://news.bbc.co.uk/1/hi/northern_ireland/4417575.stm on July 202017.

BBC (2014) 'Gerry Adams: Unionists Condemn Use of Swear Word', accessed at: http://www.bbc.co.uk/news/uk-northern-ireland-30186975 on July 202017.

Clancy, M-A. (2010) Peace without Consensus: Power-sharing Politics in Northern Ireland, Farnham, Ashgate Press).

Clinton, H. (2014) Hard Choices, New York, Simon and Schuster

Coakley, J. (2009) 'Implementing Consociation in Northern Ireland'. In R. Taylor (ed.), Consociational Theory: McGarry and O'Leary and the Northern Ireland Conflict, London, Routledge, pp. 122-145.

Coakley, J., Garry, J., Matthews, N. and Tilley, J. (2017) The 2016 Northern Ireland Assembly Election: How Voters use STV (Electoral Reform Society)

Deloitte (2007) Research into the Financial Cost of the Northern Ireland Divide (London: Deloitte).

Dixon, P. (2002) 'Political Skills or Lying and Manipulation? The Choreography of the Northern Ireland Peace Process’, Political Studies, 50, 725-41.

Evans, G. and O'Leary, B. 'Northern Irish Voters and the British-Irish Agreement: Foundations of a Stable Consociational settlement?’ The Political Quarterly 71, 78-101.

Evans, J. and Tonge, J. (2009) 'Social Class and Party Choice in Northern Ireland's Ethnic Blocs', West European Politics, 32, 1012-1030.

Godson, Dean (2003) 'Meeting of the Extremes, The Spectator, accessed at: https://www.spectator.co.uk/2003/12/meeting-of-the-extremes/\# on July 20 2017.

Guelke, A. (2017) 'The Risk to Northern Ireland', Journal of Democracy, 28, 42-52.

Hayes, B., McAllister, I., and Dowds, L. (2005) 'The Erosion of Consent: Protestant Disillusionment with the 1998 Northern Ireland Agreement', Journal of Elections, Public Opinion \& Parties, 15, 147-167.

Hayes, B. and. McAllister, I. (2013) 'Gender and Consociational Power-sharing in Northern Ireland’, International Political Science Review, 34, 123-39.

Hayes, B. and Nagle, J. (2016) 'Ethnonationalism and Attitudes Towards Gay Rights in Northern Ireland', Nations and Nationalism, 22, 20-41.

Horowitz, D. L. (2002) 'Explaining the Northern Ireland Agreement: The Sources of an Unlikely Constitutional Consensus', British Journal of Political Science, 32, 193-220.

Knox, C. (2002) 'Cohesion, Sharing, and Integration in Northern Ireland', Environment and Planning C: Government and Policy, 29, 548-566.

Matthews, N. (2012) 'The Northern Ireland Assembly Election 2011', Irish Political Studies, 27, 341-358.

McAuley, J.W. and Tonge, J. (2010) 'Britishness (and Irishness) in Northern Ireland since the Good Friday Agreement’, Parliamentary Affairs, 63, 266-285.

McCulloch, A. (2014) 'Consociational Settlements in Deeply Divided Societies: The Liberal-corporate Distinction’, Democratization, 21, 501-518. 
McCulloch, A. (2017) 'The Use and Abuse of Veto Rights in Power-Sharing Systems: Northern Ireland's Petition of Concern in Comparative Perspective', Government and Opposition, 1-22.

McEvoy, J. (2015) Power-Sharing Executives: Governing in Bosnia, Macedonia, and Northern Ireland, Philadelphia, P.A: University of Pennsylvania Press.

McGarry, J. and B. O’Leary (1995) Explaining Northern Ireland: Broken Images, London: Wiley-Blackwell.

McGarry, J. and O’Leary, B. (2006) 'Consociational theory, Northern Ireland's Conflict, and its Agreement. Part 2: What Critics of Consociation can Learn from Northern Ireland', Government and Opposition, 41, 249-77.

Mitchell, Paul (2008) The Single Transferable Vote and Ethnic Conflict: The Evidence from Northern Ireland, 1982-2007, accessed at: http://www.lse.ac.uk/government/research/resgroups/PSPE/pdf/2008conference _papers/Mitchell_STVpaper.pdf on July 202017.

Mitchell, P., O’Leary, B. and Evans, G. (2002) 'The 2001 Elections in Northern Ireland: Moderating "Extremists” and the Squeezing of the Moderates', Representation, 39, 23-36.

Mitchell, P., Evans, G. and O’Leary, B. (2009) 'Extremist Outbidding in Ethnic Party Systems is not Inevitable: Tribune Parties in Northern Ireland', Political Studies, 57, 397-421.

Morrissey, M. and Smyth, M. (2002) Northern Ireland and the Good Friday Agreement: Victims, Grievance and Blame, London, Pluto.

Morrow, D. (2015) 'Mixed Messages: Community Relations in 2014', Ark: Research Update, 105.

Murtagh, B. and Shirlow, P. (2012) 'Devolution and the Politics of Development in Northern Ireland', Environment and Planning C: Government and Policy, 30, 46-61.

Nagle, J. and Clancy, M-A. (2010) Shared Society or Benign Apartheid? Understanding Peace-Building in Divided Societies, Basingstoke, Palgrave Macmillan.

Nagle, J. and Clancy, M-A. (2012) 'Constructing a Shared Public Identity in Ethnonationally Divided Societies: Comparing Consociational and Transformationist Perspectives', Nations and Nationalism, 18, 78-97

Nagle, J. (2009) 'Potemkin Village: Neoliberalism and Peace-Building in Northern Ireland', Ethnopolitics, 8, 173-190.

Nagle, J. (2016) Social Movements in Violently Divided Societies: Constructing Conflict and Peacebuilding, Abingdon, Routledge.

Nolan, P., Bryan, D., Dwyer, C., Hayward, K., Radford, K., and Shirlow, P. (2014) The Flag Dispute: Anatomy of a Protest, Belfast: Queen's University Belfast.

Northern Ireland Office (1998) Agreement Reached in the Multi-Party Negotiations. Belfast, HMSO.

Northern Ireland Office (2014) The Stormont House Agreement, Belfast, HMSO. Northern Ireland Office (2015) A Fresh Start for Northern Ireland, Belfast, HMSO (2005) A Shared Future, Belfast: Community Relations Unit, OFMdFM. 
OFMdFM (2007) Building a Better Future: Draft Programme for Government 2008 2011, Belfast, OFMdFM.

OFMdFM (2010) Programme for Cohesion, Sharing and Integration: Consultation Document, Belfast, OFMdFM.

O'Leary, B. (1997) 'The Conservative Stewardship of Northern Ireland, 1979-97: Sound-bottomed Contradictions or Slow Learning?’ Political Studies, 45, 663676.

Ruggie, J. (1993) 'Territoriality and Beyond: Problematizing Modernity in International Relations, International Organization, 47, 139-174.

Russell, R. (2011) Northern Ireland Assembly Election 2011, Northern Ireland Assembly: Research and Information Service Research Paper.

Russell, R. (2016) Election Report: Northern Ireland Assembly Election, 5 May 2016, Northern Ireland Assembly, Research and Information Service Research Paper.

Russell, R. (2017) Election Report: Northern Ireland Assembly Election, 2 March 2017, Northern Ireland Assembly, Research and Information Service Research Paper

Schwartz, Alex (2017) 'Mitigating the Hazards of Brexit: The EEA Option for Northern Ireland', UK Constitutional Law Association, accessed at: https://ukconstitutionallaw.org/2017/03/27/alex-schwartz-mitigating-thehazards-of-brexit-the-eea-option-for-northern-ireland/ on July 202017.

Shirlow, P. and Murtagh, B. (2006) Belfast: Segregation, Violence and the City, London: Pluto.

Taylor, R. (2006) 'The Belfast Agreement and the Politics of Consociationalism', The Political Quarterly, 77, 217-226.

Tonge, J. (2005) The New Northern Irish Politics, Basingstoke, Palgrave Macmillan.

Tonge, J. (2016) 'The Impact of Withdrawal from the European Union upon Northern Ireland', The Political Quarterly, 87, 338-342.

Whyte, J. (1981) 'Why is the Northern Ireland Problem so Intractable?' Parliamentary Affairs, 34, 422-435.

Wilford, R. (2010) 'Northern Ireland: The Politics of Constraint', Parliamentary Affairs, 63, 134-155.

Wilford, R. and Wilson, R. (2006) The Trouble with Northern Ireland, Belfast, Democratic Dialogue. 